UDC 316.776.33:316.35

DOI https://doi.org/10.32838/2663-6069/2020.2-4/19

Zabotnova M. $V$.

National Academy of the National Guard of Ukraine

\title{
MANIPULATION OF MASS CONSCIOUSNESS CARRIED OUT BY INTERNET MEMES ON POLITICAL CAMPAIGNS
}

\begin{abstract}
The article is devoted to the manipulation of mass consciousness carried out by Internet memes on the material of political campaign. It highlights the main features of memes'formation and their role in modern social networks including the most wide-spread Facebook, Twitter, MySpace and Instagram. It presents various ideas on the topic by numerous scientists from the psycholinguistic point of view. The article is aimed at the analysis of Mandela Effect's role in the manipulation of mass consciousness at the chat-speak territory of cyberspace as well as at the presentation of basic data which is focused on proving the memes possibility to manipulate the Internet audience to form required attitude to the definite situation. The whole work is based on the studies of the cyber-memes with political content due to the huge range of various political parties and mock-wars among political powers of the world which may have impact on the political situation worldwide. The work includes the descriptions of key ways of purposely created memes activity and their possibility to be synchronized with the phenomenon such as Mandela Effect. It proposes the core features which serve as hand of help on the way to the implementation of political intentions through memes basing on frames, words, colours and backgrounds used in the process of their developing to create needed atmosphere and reactions of the Internet-users. The main tasks which are followed in the article are to highlight the principles of memes' formation, to give the basic information on Mandela Effect proposing examples to prove its role in manipulation of mass consciousness and to provide initial information concerning the way the influential actions work.
\end{abstract}

Key words: memes, manipulation, mass consciousness, Internet, communication, political campaign, critical thinking.

Description of the problem. Modern society from year to year multiply own possibilities and ways of communication and interaction. Especially it is seen from the numerous social networks which continue growing in numbers including Facebook, MySpace, Twitter and Instagram. That happens due to digitalization and due to the large amount of information individuals have to share and to exchange. But information is something more than simple news and stories to be retold or spoken out loud - information is a kind of weapon which may help to achieve goals or to change attitude of the audience to one or another definite situation. It is considered that it is not an easy task to manipulate the mass consciousness, but here the Internet-users mislead themselves into a false understanding of the general picture of how the mass manipulation work. People take the information as something they up to decide without even understanding that there are not much things they may take and decide by their own and this papers will return to this field a little bit later. In this article it is proposed to discuss the possibilities of Internet and its communicative means such as memes to influence the users' attitude to the situation or to manipulate users' ideas changing their thoughts in accordance with the needs Internet-runner follows.

The urgency of the article is formed due to the uncontrolled number of means which are turned to influence mass consciousness with the help of widely spread memes as well as due to the challenges which are posed by trendy ways of interaction such as social networks which create psycholinguistic units of mass consciousness manipulation; that forms a strong need in developing critical thinking in Internet users as a way of their manipulation resistance.

The analyses of recent researches on the topic. Nowadays there are numerous linguists, psychologists and psycholinguists who address their works to research the mentioned field, number of them is turned to the analysis of political side of the problem; among the scientists it is possible to highlight the following: S. Arifkhanova [4], V. Chernikova [3], C. Worsnop [6], R. Dawkins [8], O. Prokofieva [13] and many others.

Task posing. The aim of the article is to figure out the memes possibility to manipulate the mass consciousness of Internet audience to form a required attitude to the definite situation on the material 
of political campaigns. To achieve the aim, it is required to complete the following tasks:

1) to highlight the principles of memes' formation;

2) to give the basic information on Mandela Effect proposing examples to prove its role in manipulation of mass consciousness;

3) to provide initial information concerning the way the influential actions work;

4) to propose the ways of manipulation resistance based on critical thinking development.

The main body of the article. In today's world, society is exposed to a great deal of information about human behavior - some of which is accurate and much of which is not. Especially in the popular media, people encounter oversimplifications, overgeneralizations, and pseudoscientific misinformation - bunk and psychobabble that is made to sound scientific and what is more - real [11]. Every separate user considers him/herself to have critical-thinking and, thus, the possibility to filter and clear-up the information which passes through them every time he/she gets access to social networks. But is it true that simple Internet user can understand and figure out every attempt of a manipulation factor? How does it work? If you think that such passages have something illogical or brightly attractive - this idea is false because manipulative posts have nothing to recognize them in endless flow of others. The more digital communication develops the more means are to be involved into the process of manipulation.

Today's level of users' informatabity is unlimited - everyone is familiar with the fact that they are influenced throughout social networks. But the way of this influence is unclear and, sometimes, is consid- ered by Internet-users to be unimportant. This work is to distinguish whether it is possible to be influenced by trendy digital mean such as meme on the materials of political campaigns. Nowadays almost every human is familiar with the concept meme.

It has been firstly coined out by the famous English ethologist and revolutionary biologist R. Dawkins in his book "Selfish Gene" [9] in 1976 where he pointed out that memes are the units which work as genes which can transmit, store and pass information not only from one person to another, but from one generation to another. The bright example in this situation is the Internet which can rework billions of informative posts from various topics per second, here users should keep in mind that at least a half of this information is checked, proven, unharmful or even safe for human consciousness. Today the word "meme" is known by every single Internet user, but not everyone clearly understands the real it may have. Mostly, people pay attention to bright and funny pictures they contain, but not to the hidden information which may be represented in the most unpredictable ways. Thus, some scientists have started paying attention to manipulative features memes may have. Hidden manipulation tends to be spread throughout social networks especially if the talk is about politics. According to O. Prokofieva "Manipulators of the type "controller" tend to expose emphatically critical position and to count up the actions of others and their constant disapproval. Manipulation involves intentional exaggeration of the importance of rules and procedures, and also in categorical statements, assessments of people and events. Social benefit lies in obtaining material goods and favours for their deviation from the rules, and also in recognition

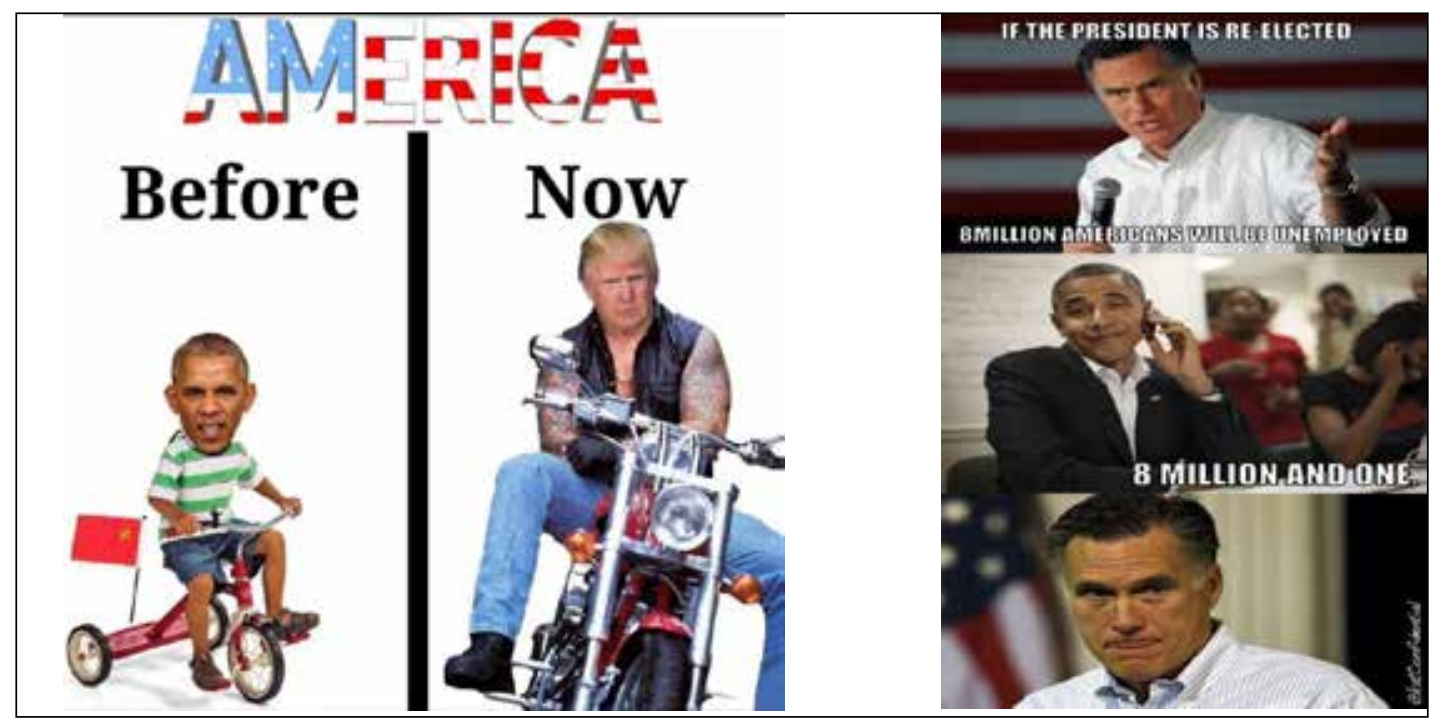

Pic. 1. "Before and Now" [10]

Pic. 2. "8 Million" [10] 
of someone's mistakes and guilt. They get psychological benefit from partner's confusion, fear and helplessness, from admiration by their environment" [13, p. 88]. Manipulative memes have much in common with recognition of someone's mistakes and guilt, which is often seen in memes with political content. That helps to develop doubts in the Internet users concerning political powers and their campaigns in general. Even if the choice is already done such psycholinguistic units can make people unconsciously hesitate and, finally, change their opinion. Today there are hundreds of social pages in networks which are devoted to the political memes only. At first sight users may see them as part of entertainment, but at second sight such units may be observed as intentively created ones to control and even to form required mood on the Internet.

To see how it works let's look through several examples of memes with political content which present two popular politicians of the modern political arena - Ex-president of the USA Barack Obama and current President of the USA - Donald Trump, the quantity of memes which are based on these politicians is huge in number (pic. 1,2).

Manipulation today is a touchy subject. Moreover there exist dozens of definitions of this process. In the frames of our research it is useful to accept the definition proposed by E. Dotsenko who pointed out that manipulation is "a type of psychological influence when the manipulative skills are secretly used by the master to pose to the user's consciousness the aims, wills, intentions, attitudes and tasks which have nothing in common with current user's ideas. As well, that is the psychological influence aimed at changing the directions of another individual's activities in the way that is kept unnoticed by him/her" [1, p. 52]. So, "unnoticed" seems to be the key word, especially if we talk about so widely-spread memes.

Now, there arises another question - how we can be influenced meeting single meme which has been, probably, intentively created. The answer is simple, even if we can remember only one meme with this picture that does not mean that there have not been others with the same hidden content. And here the place is granted to Mandela Effect. The concept "Mandela Effect" has been coined out in 2013 after the death of the African political leader Nelson Mandela. That happened because millions of people worldwide were thinking that the African politician had died not later than in 1980s being imprisoned. In fact, Mandela was released in 1990 and passed away in 2013 - but this information was not so wide-spread. This situation has created a line of familiar events. Psychologists suppose these collective misrememberings can be mostly put down to memory distortions and what's known as "the misinformation effect". This is where information you learn after an event can interfere with the way you recall it [15].

Moreover, Mandela Effect often works with the range of means based mostly on the visual support. This factor is basic to form the required persuasive reaction. It is almost impossible to make Mandela Effect work without any visual and digital assessment. Thus, it is easily applied to cyber-memes with political content and is widely used by various political powers, parties as well as campaigns. Among vast range of features which may help to create manipulative posts it is possible to enlist the following:

1) frames - it seems that this aspect of memes does not have any values and does not play any role in manipulative actions. But this statement is considered to be false. Due to the researches conducted concerning the power of colours, the same scheme can be easily applied to memes. Psychologists have pointed out that colours have controversial influence on human consciousness: their behavior, relations, mood, education and decision-making [2, p. 1]. As we can see on the Picture 3 - black frame accompanies the content concerning the politician. This colour is the colour of darkness and is perceived as a depressive and negative [2, p. 3], but such negativism can be used not just concerning the figure on the meme, but concerning the opponents it addresses to. In such cases frames work together with the content;

2) dominant colour - in the frames of our research colours play an essential role. Dominant colour - is the colour which is the main one on the meme - warm colours arise positivism when cold ones - negative attitudes;

3) content formation - the content can be divided into three big groups: positive, negative and neutral. Neutral content does not have much powers in manipulation, but may occupy first place in misleading and fake information. Memes with positive content are developed to create good attitude to the politician and, at the same time, to darken the opponent. Memes with negative content may have two hands one belongs to the rival and this situation is quiet logical, but there may exist examples when the talk is about black-PR, in such cases negative information is introduced by the group of the politician her/himself to arise attention to this individual;

4) colour of the passage - here the situation is equal to the one which happens with dominant colours and frames - throughout the social networks it is 
possible to see numerous posts created in black-andwhite (pic. 4), thus, it can be pointed out that those two colours are dominant for the content brightening;

5) background - important role is posed to the background; it serves as a basic assessment in creation the general mood of memes. As it is seen from picture 5 - bright background (especially with appropriate addressing) may arise the level of positivism while the dark and uncertain background may have fully opposite result as well as reaction;

6) main character - person who is the key figure of the post is another factor of correct effect creation. Huge role is granted to the emotions she/he presents - laugh, smile, cry, angry posture, etc. - to develop the required attitude every detail of the post is to be estimated;

7) addressing - this factor is very common and has much in common with the theory of strategic communication. Such memes may contain statements or backgrounds which apply to the individual's values of different kind - family, religion, race, nationalism, friends, enemies, celebrities, etc. Such addressing may provoke great range of emotions which, in return, can create definite atmosphere and mood which is needed to have enough quantity of manipulative powers. Nothing runs person's decisions more than personal addressing - that makes every individual feel her/ himself as a part of the group and the politician her/ himself becomes an essential part of the voters' life, or, if addressing is negative and has been purposely created by opponents - such addressing may have controversial results and can lead to the complete ruining of the politician's campaign.

Another question is how can all these factors work? The answer is quite simple - our brain can remember more than our eyes do. Moreover, it can keep and notice the information the individual has not even paid attention to. It happens automatically. The more often we meet the same memes' content the more chances arise that our brain will definitely remember it and will further accumulate as our own one, in other words - produced by our own brain activity. This cat will jump quite high in cooperation with Mandela Effect.

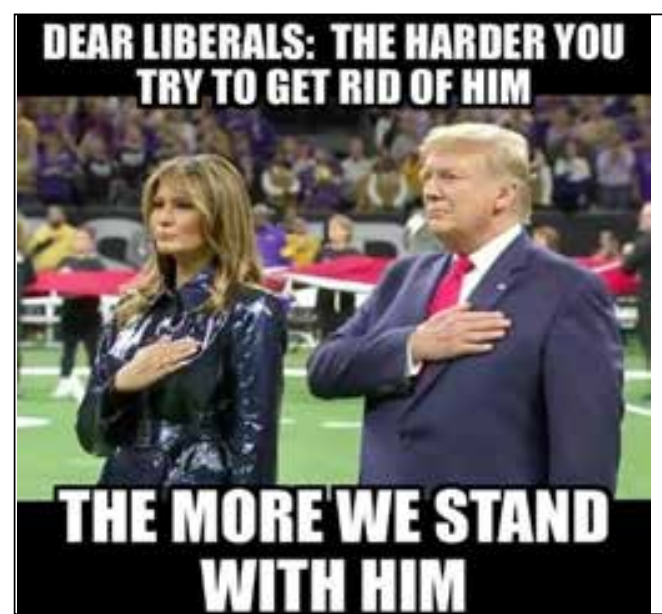

Pic. 3. "Black Frame" [12]

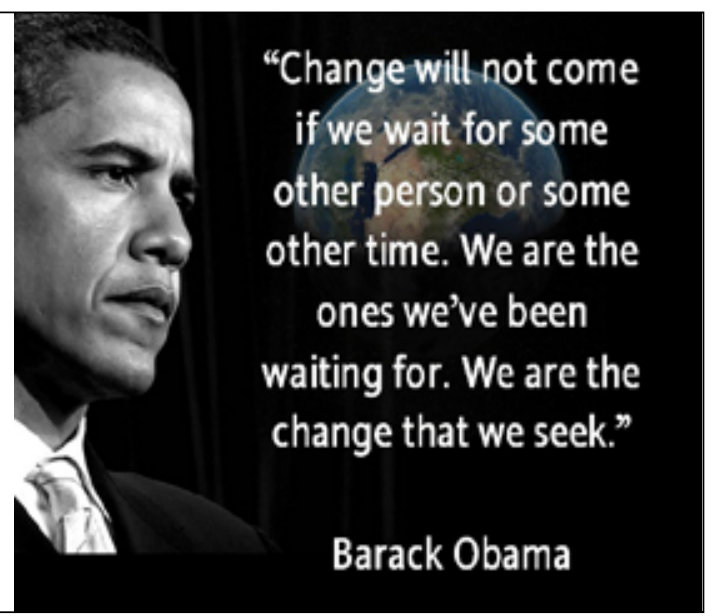

Pic. 4. "Black-and-white" [12]

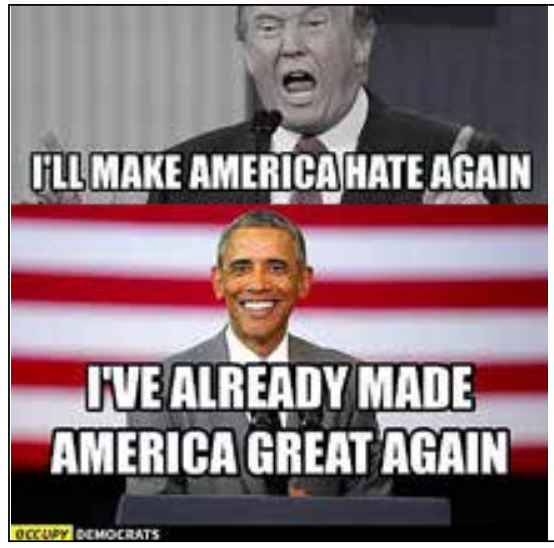

Pic. 5. "Background" [12]

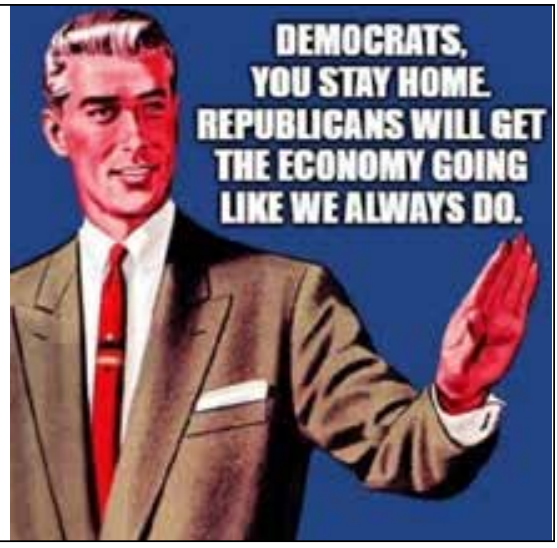

Pic. 6. "Main Character" [12] 


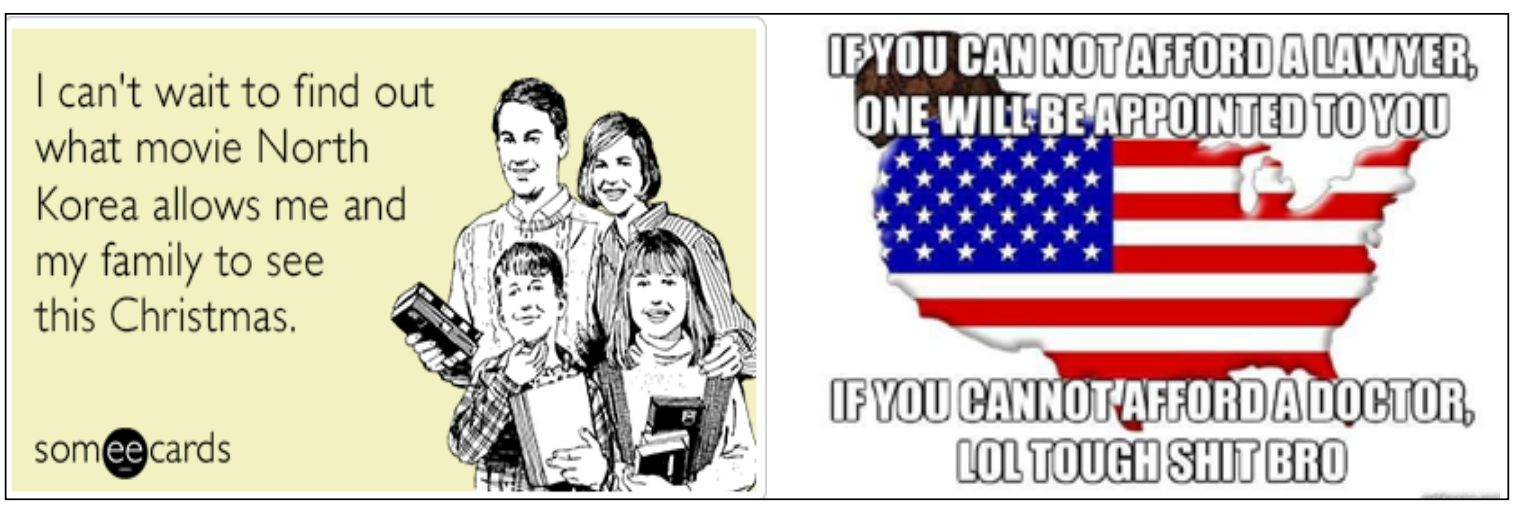

Pic. 7. "Addressing to the family" [12]

Pic. 8. "Addressing to national values" [12]

Nevertheless, everything is not as bad as it seems. Battle with fake information can be won if individuals query every piece of information they meet. To succeed with the task individuals are to develop their own critical thinking because that is the only path to media literacy that can help to resist fake, unchecked or purposely created information as well as facts. Remembering Bloom's Taxonomy it is useful to stress out that the ability to analyze occupies the fourth place out of six (remembering, understanding, applying, analyzing, evaluating and creating) [5]. Ability to analyze is to be the core issue of manipulation resistance. Thus, critical thinking is essential and can not be substituted with any other feature of individual social development. According to Robin Wood "critical thinking is the process of using reasoning to discern what is true, and what is false, in the phrases and "sound bytes" we hear everyday. Critical thinking can not only make you manipulation proof, it can open new vistas for you, as things previously hidden become clear" [14].

Conclusions. So, to develop manipulation resistance to cyber-memes, individuals are to develop critical thinking to acquire possibility to analyze and evaluate every piece of information they meet. The main task is not to understand that Internet-users are manipulated with their decision-making, but to see those means and have correct automatic reaction that is impossible without querying and analyzing. Every individual should keep in mind that memes - are the means of information presenting, but not every information is true or full, everything is to be analyzed and estimated.

\section{References:}

1. Доценко Е. Психология манипуляции: феномены, механизмы и защита. Санкт-Петербург, 2003. 304 с.

2. Коробій С. Психологічний вплив кольору. URL: http://ena.lp.edu.ua/bitstream/ntb/17830/1/107Korobiy.pdf.

3. Черникова В. Манипуляция массовым сознанием как феномен информационного общества. Теория и практика общественного развития. 2015. № 3. С. 141-144.

4. Arifkhanova A. Manipulation of social consciousness through mass media. 2010. URL: http://www.socialpsychology.org/download/111626/Article7PDF.pdf.

5. Armstrong P. Bloom's Taxonomy. Center for Teaching. URL: https://cft.vanderbilt.edu/guides-sub-pages/ blooms-taxonomy/.

6. Worsnop C. Media Literacy Through Critical Thinking. URL: http://depts.washington.edu/nwmedia/ sections/nw center/curriculum docs/teach combine.pdf.

7. Daily Trump Memes. URL: https://www.facebook.com/Dailytrumpmemes/.

8. Dawkins R. Memes. 2014. URL: https://www.youtube.com/watch?v=4BVpEoQ4T2.

9. Dawkins R. The Selfish Gene. 30th Anniversary Addition. Oxford : Oxford University Press, 2006. 384 p.

10. Obama Memes. URL: https://www.facebook.com/Obama-Memes-161239390687403/.

11. Passer M., Smith R. Psychology. The Science of Mind and Behavior. Boston ; London : McGraw-Hill Higher Education, 2009. 665 p.

12. Political Memes. URL: https://www.facebook.com/TheMemeRevolution/.

13. Prokofieva O. Psychological conditions of preventing manipulative interpersonal relations in adolescence. Наука і освіта. 2015. № 7. С. 87-92.

14. Wood R. Critical Thinking. URL: https://www.robinwood.com/Democracy/GeneralEssays/ CriticalThinking.pdf.

15. Keaveny P. The "Mandela effect" and the science of false memories. The Conversation Trust. 2019. URL: http://theconversation.com/the-mandela-effect-and-the-science-of-false-memories-114226. 


\section{ЗабоТНОВа М. В. МАНІПУЛЯЦІЯ МАСОВОЮ СВІДОМІСТЮ ЗА ДОПОМОГОЮ ІНТЕРНЕТ-МЕМІВ НА МАТЕРІАЛІ ПОЛІТИЧНИХ КАМПАНІЙ}

Статтю присвячено проблемі маніпуляиії масовою свідомістю за допомогою інтернет-мемів на матеріалі політичних кампаній. Уроботі висвітлені основні шляхи створення мемів та їх роль у сучасних соиіальних мережсах, зокрема Facebook, Twitter, MySpace ma Instagram. Cтаття надає широкий спектр аналізу робіт науковиів із боку психолінгвістики за темою дослідження. Метою є дослідження ролі ефекту Мандели в маніпуляиії масовою свідомістю на просторах чатів кіберпростору. У статті представлено низку основної інформачї стосовно підтвердження здатності мемів впливати на свідомість інтернет-користувачів для формування в них бажаного ставлення до відповідної ситуачії. Загалом робота спирається на дослідження кібер-мемів із політичним змістом через низку актуального матеріалу стосовно політичних партій та війн між політичними силами на всесвітній арені, які мають вплив на політичний устрій світу. Стаття містить детальний опис ключових способів роботи мемів, щзо створені з виключною метою, та їх здатності до синхронізації з таким феноменом, як ефект Мандели. У статті пропонуються основні ознаки, які допомагають втілити в життя політичні наміри діячів через меми зі зверненням уваги на їхні форми, межі, кольори та фонові зображення, що використовуються у прочесі створення бажаної атмосфери та реакції інтернеткористувачів. Для досягнення мети в роботі було поставлено низку завдань: висвітлити принципи творення мемів; надати основну інформачію стосовно ефекту Мандели з наведенням прикладів для підтвердження ролі иъвого ефекту в маніпулюванні масовою свідомістю; визначити основні принципи роботи маніпулятивних дій стосовно політичних діячів світової арени.

Ключові слова: меми, маніпуляиія, масова свідомість, інтернет, спілкування, політична кампанія, критичне мислення. 